\title{
John Denham
}

The last 12 months have seen significant developments in the co-ordination of activity on the debt crisis by European non-government organisations (NGOs).

European NGOs exist in many different forms. Many give financial support to grass-roots projects in Third World countries, using funds raised from the public and through the aid administrations of their governments. Most of these also carry out some educational and lobbying work amongst their supporters and with their governments. Others concentrate purely on educational, political lobbying and solidarity work. The constituencies of the NGOs cover a wide range of political viewpoints, and different NGOs are associated with a range of religious and secular groups.

Concern about the debt crisis has risen steadily throughout the 1980s, and has recently become particularly marked amongst the project funding agencies. Many have seen their grass-roots work overwhelmed by the negative impact of the debt and the consequent adjustment policies. The need to respond to this experience has been reinforced by pressure from partner agencies in Third World countries to campaign on the issue.

In recent years, there have been many campaigns in individual countries, most of which have aimed to persuade governments to extend relief on official debt to the poorest sub-Saharan African countries. Though the results have been limited, it is generally accepted that public pressure helped to create the political initiatives which led to the Toronto agreement. Other campaigns have concentrated on commercial debt and the problems of middle-income debtor countries. A third, and more specialised line of lobbying has been directed at adjustment policies and at the World Bank in particular.

The coordination between national initiatives has, until recently, been limited. However, since March 1989, a grouping of NGOs from 11 count ries has been developing a common European debt campaign.

The initial focus of the campaign is to be the debt owed to European banks and the need for a more coordinated (and sympathetic) response to the crisis from European governments and financial institutions.

The simple premise underlying the campaign is that debt relief should be great enough to ensure each country has sufficient resources to allow sustainable economic recovery and development to take place. No figure on the level of debt reduction needed has been set, although the campaign refers to a variety of projections, including those from the World Bank, UNCTAD and WIDER that imply debt/debt service reduction of upwards of 40 per cent for major debtor countries.

In practice, many NGOs will be advocating at least 50 per cent debt/debt service reduction for the major debtors and the total cancellation of debts owed by the poorest countries.

In addition, the campaign will press for action on capital flight, including the identification of capital flight assets and will be arguing that certain loans such as those tainted with fraud or corruption should be regarded as illegitimate.

The campaign will be pursued in different ways in different countries but, at a European level, a 'twintrack' strategy will be pursued. All the major commercial banks will be approached directly and asked to respond to an appeal endorsed by over 50 NGOs. The appeal asks banks to accept the principle of the campaign and publicly support action on debt reduction, capital flight and illegitimate loans.

Though no major sudden change in banks' policies may be anticipated, the involvement of major and respected NGOs will add a significant new presure on the banks. This is particularly true in those countries where banks are subject to competition from other financial institutions offering personal banking services.

At the same time, Parliamentarians throughout Europe are being asked to support a joint letter addressed to Finance Ministers and the President of the European Community which urges more radical action on debt relief. This in itiative stresses the need to go beyond the reliance on the voluntary participation of banks in any debt reduction strategy. It also stresses the current lack of European influence in the evolution of the debt strategy and the need to raise European concerns which are (or should be) different to those of the USA and Japan.

While the campaigning action around bank debt is now getting underway, initial plans are also being made for a parallel campaign aimed at increasing 
levels of official debt relief.

The campaign, while developed and run by NGOs, has been able to draw on the advice of several leading academics in Europe and a valuable partnership is developing through which the complex realities of the debt crisis can be translated into clear and simple messages for the public, media and politicians. The participating NGO also lay great stress on using the campaign to promote the views and experiences of their southern partners.
The campaign is currently serviced by a Dutch-based NGO, FONDAD ${ }^{1}$ which stands for the Forum on Debt and Development a name which emphasises the strong conviction of participating NGOs that the failure to deal adequately with the debt problem puts in jeopardy the prospects of development for people in many Third World countries.

${ }^{1}$ FONDAD, Norrdeinde 107a, 2514 GE, The Hague, The Netherlands. 